\title{
COVID-19: IMPACT OF LOCKDOWN ON TOURISM \& HOSPITALITY INDUSTRY
}

\author{
Amit Joshi \\ ICFAI business school, ICFAI University, Dehradun, Uttarakhand, India \\ insojtima@gmail.com \\ Preeti Bhaskar \\ University of Technology and Applied Sciences, Ibra, Oman \& ICFAI University, Dehradun, \\ Uttarakhand, India \\ preeti.bhaskar52@gmail.com
}

\begin{abstract}
As countries are isolating themselves from rest of the world to secure themselves from the pandemic- COVID 2019 , it is definite imperative that the world economy will suffer a deep adverse impact. Amidst lockdown imposed by the Indian government, it is paramount to understand which companies are predominantly adversely affected and how those companies are managing their human resources. The authors initiate to divulge the consequences of lockdown arising because of COVID19 on the Hospitality and Tourism sectors in India. It also showcases its impact on the employees working in these organizations and the remedial measures that are being adopted by them. The significance of the article is that it gives an understanding of the unique HR policies that are being adopted by the companies in dire circumstances to assist and facilitate their employees. The article extends certain suggestions to the Government that may be adopted to retrieve the Tourism and Hospitality from financial burden and curb unemployment.
\end{abstract}

Keywords: Hospitality, Lockdown, Pandemic, Tourism, Unemployment

\section{INTRODUCTION}

Chinese authorities on January 7, 2020, identified the virus causing pneumonia in Wuhan city as a novel coronavirus. It was a new virus that was never seen in humans. The virus started spreading not only in China but also outside China. Due to its rapid spread and non-availability of its vaccination, it was declared a pandemic by the World Health Organization on March 11, 2020 (World Health Organization, 2020a). More than 25,602,665 people around the world are affected by the deadly virus and the number is leaning dangerously. The number of deaths due to COVID19 is also increasing at an alarming rate, more than 852,758 have lost their lives (World Health Organization, 2020b). The number of cases in India saw a dramatic increase across the states and union territories. Most cases in India are due to local transmission of people who had a travel history from coronavirus infected countries. According to the Ministry of Health and Family Welfare, there are 815538 active infected cases and 67376 people have died across India 
(MoHFW, 2020). On 25.03.2020, the Indian Prime Minister took a precautionary step to secure the Indians from getting infected from the COVID-19 virus, he declared complete lockdown for 21 days, it included schools, offices, factories, parks, temples, railway stations, and even the airspace. Though the decision was taken to keep the citizens safe, it had an adverse impact on India's informal economy, which constitutes a huge share of the workforce (Kapoor, 2020). With the world economy badly hit, the economy of India is preparing for the fallout of COVID-19. As per the report of Asia Development Bank (ADB), the pandemic is expected to cost the Indian economy between $\$ 387$ million and $\$ 29.9$ billion in personal consumption losses. ADB's report was based on the situation when the outbreak was dominated in China, with $97 \%$ of fatalities and $93 \%$ of total cases (Mishra, 2020) but in the present scenario, USA and Italy have surpassed China, and the situation of India is becoming critical day by day. The rising number of infected people may have an unpropitious catastrophic effect on the economy of India. According to the Economy Forecast of Dun \& Bradstreet's, there is a huge probability that India may enter into recession and companies may become bankrupt (Press Trust of India, 2020a). The lockdown in India is a viable measure to control coronavirus COVID-19, but as apprehended its extension will put India under doldrums and it may be struck by poverty and unemployment (Joshi, et al., 2020). Most of the strongest economies around the globe are struggling to cope with the situation in the wake of an unprecedented demand shock and a shutdown of all key economic activities that drive growth. Many Indian sectors are now in critical need of a relief package. According to the report of the UN Conference on Trade and Development, India may lose $\$ 348$ million and maybe among the top 15 most-adversely affected economies after the EU, United States, Japan, and South Korea (Asian Development Bank, 2020).

In the present scenario, the Tourism \& Hospitality Industry got hit hard by COVID-19 and the road ahead does not seem to be too good. During the month of January 2020, the threat of COVID19 was spreading; the tourism industry was the first to bear the brunt with reservation of hotels and airlines being cancelled. To restraint, the outbreak of epizootic disease Indian government suspended the Visas, grounded all flights and tourist attractions are shut indefinitely, thus imposing a stricture on the value chain of tourism which includes hotels, tour operators, restaurants, and agents. The whole chain of tourism and hospitality is expected to face huge losses worth billions. It is expected that the tourism industry in India will take an enormous hit and it may be crippled for the anticipated ensuing days. Though, during these difficult times, many companies have taken some good initiative to curb mass unemployment, but the question remains whether the industry will be able to sustain in the long run. To do business and earn sustenance, tourism and hospitality rest on trade and travel, both were put to a halt as the fear of pandemic gripped the world, Hotels are closed, people are not allowed to travel results in a devastating impact on jobs. The sector is 
facing decline revenues, but expenditure almost remains the same. Companies need to bear the fixed cost with the additional responsibility of paying staff salaries.

\section{IMPACT ON TOURISM \& HOSPITALITY INDUSTRY}

Tourism is an important sector in India, attracting domestic and foreign nationals throughout the year. Tourism and hospitality industry contribute significantly to the economy and generates huge employment directly and indirectly. During the last three decades, this sector has seen a change in the trend, with the increase in the numbers of national and international tourists and it also contributes a significant amount in the Gross Domestic Product of the country. Due to the lockdown, the whole India was seized; the two most prominent sectors to get impacted by this situation were Hospitality and Tourism. Some of the worst-hit sectors in India include the tourism and hospitality industry. The direct and indirect economic impact of the pandemic and the lockdown on the tourism industry in India is estimated at about $10 \%$ of India's GDP.

Confederation of Indian Industry (CII) estimated loss of revenue to tourism to range between Rs 72,000 crores and Rs 1.58 lakh crores in 2020-21 (Chatterji \& Dutta, 2020). The Federation of Associations in Indian Tourism \& Hospitality (FAITH) projected that due to lockdown 38 million people may remain unemployed which otherwise were working in the tourism and hospitality sector (Nebehay \& Mutikani, 2020). FAITH estimated that value at risk can reach almost ₹20 lakh crore in the whole tourism value chain across airlines, travel agents, hotels, tour operators, tourism destinations restaurants, tourist transporters and tourist guides (Chaturvedi, 2020).

\subsection{HOTEL SECTOR}

The hotel sector is an important value chain of the hospitality and tourism industry. According to the tourism ministry, branded hotels will take the biggest hit in the tourism sector, followed by tour operators (Chatterji \& Dutta, 2020). The hotel industry in India is witnessing a huge dip in occupancies, revenues, and ceremonies for the current quarter. Future bookings are also getting stalled due to the Coronavirus effect. The customer spectrum of hotels in India comprises $76-77 \%$ domestic travellers and the share of tourists coming foreign from countries is close to $23-24 \%$ (Biswas, 2019). Due to the virus outbreak hotel occupancy in the whole country has witnessed a 40\% drop year on year for March 2020 credit rating agency reduced the interpretation on the hospitality sector from stable to negative (Mohile \& Aute, 2020). The situation looks grim and if the situation continues the hotel industry will take a massive job loss hit. Industry is working on cost-cutting by laying off the temporary and contractual workers but is continuing with the employees. Few employees have been asked to go on paid leaves while the remaining are still working in the hotels, thus the operational cost is reduced. Hyatt decided to lay off 1,300 employees' 
members but also offered severance pay to lay off employees and also decided to pay cut for senior management, board members and all other employees as pandemic cripples the hotel revenue (ET Hospitality World, 2020). Understanding the situations, hotels are converting the room into isolation wards thus keeping the staff engaged and generating revenue. Many hotels have extended their help in this pandemic situation. Lemon tree, Radisson hotels, Taj group of hotels, and international hotel groups have collectively offered 392 rooms as paid quarantine facilities for the "Vande Bharat Mission" (Singh, 2020). This step will not only strengthen the country to fight the epidemic but also keeps the workers employed. The Hotel Industry is expecting that the effect of lockdown will continue for a long period of time and is gearing up to create the belief among the customers and return back into the business. Majority of hotel operators expect up to 2 years for revenue recovery from COVID-19 pandemic impact (Press Trust of India, 2020b).

\subsection{AVIATION SECTOR}

The Aviation sector is an important value chain of the tourism industry, which is also influenced largely by COVID-19 and facing major financial loss and massive unemployment. Centre for Asia Pacific Aviation (CAPA) expects domestic traffic to decline by over $60 \%$ and international traffic by $70-80 \%$ in financial year 2021 operators (Chatteri \& Dutta, 2020). According to credit rating agency CRISIL, Indian airlines will face a revenue loss of $\$ 1.3$ trillion between fiscal 2020 and 2022 because of the pandemic. According to the International Air Transport Association (IATA), airlines in the Asia-Pacific region will be the hardest hit by the health crisis, with losses expected to be around $\$ 29$ billion for 2020 (Asian Aviation Staff, 2020). The coronavirus and unemployment have become synonymous with each other, it is estimated that close to 600,000 supporting or ground jobs are at risk in the aviation sector (Das, 2020). The crucial aviation sector that connects nations across the world is witnessing a flurry of layoffs and pay cuts. Some workers have been asked to go on forced unpaid leaves by aviation companies, who have been hit equally hard as the tourism and hospitality sector. The aviation sector is under a lot of pressure to sustain themselves in this difficult situation by taking appropriate measures for managing its employees. Go-Air initiated a momentary rotational leave without pay program for helping the company to face the short-term depletion in employee's magnitude to ensure business continuity. Similarly, Vistara to curb its cost announced 1 to 3 day's mandatory leave without for $30 \%$ of its 4,000 employees (Chowdhury, 2020a). Initially, Indigo Airlines announced a systematic pay reduction following the hierarchy. People in the high position were asked to sacrifice $20 \%$ of their salary and middle-level management had a $15 \%$ deduction in their salaries (Chowdhury, 2020b) but the continuous losses made huge impact and IndiGo decided on reducing its employee count by $10 \%$ to survive the downturn (Sinha, 2020). The pay cut strategy of $5 \%$ was even 
implemented by Air India (Press Trust of India, 2020c). Airlines are planning to keep for a month 35\% of its employee on leave without pay and in order to support the airlines, they have proposed a $20 \%$ salary deduction for staff in a staggered manner (Press Trust of India, 2020d). Air India employees decided not to lay off any employees and decided to pay the flying allowances to pilots as per the actual flying hours in a month (Sharma, 2020).

\section{CONCLUSIONS}

The tourism and hospitality industry have reached a staggering halt; travel, hotel, and aviation are suffering in the present adverse situation. Even if the Covid-19 situation improves, the recovery of the industry will still take at least 8-10 months. Private companies without government financial support will not be able to recover. Many tourism, hospitality, and aviation companies have requested the government for an interim bailout package to pay instalments and employees' salaries. Till the next fiscal year, it seems that the recovery for the industry is difficult. For the future, the government needs to take some constructive measures, though the government is already providing monetary support to daily wage earners, in the same may be advanced to staff working in the hospitality and aviation industry as they are the driving force of the tourism industry. The government may implement tax abatement to boost the aviation and hotel industry, a cut in the Goods and Service tax will augurs well for the tourism and in turn, will benefit the entire value chain. It will have a cascading impact and will increase employment. The government may permit a few hotels to become functional, but they cannot expect a huge turnover of tourists. So they have to reduce their cost by providing a simple menu, using machines to clean rather than human force, mandatory digital payments, closing restaurant and use of room service, strictly follow the literature for sanitization, and other measures that may minimize the human contact and imbibe faith of safety among the customers. Airlines may prioritize profitable routes over increasing market share, giving more pricing power to airlines, and providing fuel at a subsidized rate will reduce the operational cost and will motivate the industry. The whole process is a vicious circle where the government financially supports the tourism industry which in turn keeps the employment of their employee intact. The security provided by the Employers during this time of crisis will generate a sense of belongingness to the employees, thus having a positive employer-employee relationship. Some other measures that may be considered are cancellation of equated monthly instalments for loans, deferment of all statutory dues, increase in provident fund, slacking customs duties, waiver in state government-level excise fees, tax holidays, abolition of power and water charges. With a bailout package in place by the government, it can be expected that both the sectors will come out with favourable market policies which will create continuous growth in the tourism 
sector and will benefit the Indian economy as a whole. One positive impact on either of the industry will have repercussions on the other industry and will again bring India back to its growth trajectory.

\section{REFERENCES}

Asian Aviation Staff (2020). IATA: \$29 billion loss expected for Asia-Pacific airlines due to COVID-19. Retrieved from Asian Aviation website: https://asianaviation.com/iata-us29-billion-loss-expected-forasia-pacific-airlines-in-2020-due-to-covid-19-pandemicl (Accessed on: 03/ September / 2020).

Asian Development Bank. (2020). The Economic Impact of the COVID-19 Outbreak on Developing Asia. In Asian Development Bank. Retrieved from https://www.adb.org/sites/default/files/publication/571536/adb-brief-128-economic-impact-covid19developing-asia.pdf (Accessed on: 15/ April/ 2020)

Biswas, J. (2019). India's Hospitality Industry: Prospects and Challenges. [online] www.magzter.com. Retrieved from https://www.magzter.com/article/Business/Hotel-Business-Review/Indias-HospitalityIndustry-Prospects-And-Challenges. (Accessed on: 14/ April/ 2020)

Chatterii, S., \& Dutta, A. (2020). Aviation industry may take a big hit: Govt note. Retrieved from Hindustan Times website: https://www.hindustantimes.com/india-news/aviation-industry-may-take-a-big-hitgovt-note/story-plS4Dhx3zpcYnRCSMd3Ahl.html (Accessed on: 03/ September / 2020)

ETHospitalityWorld.com. (2020). Hyatt to lay off 1,300 employees as pandemic cripples travel - ET HospitalityWorld. Retrieved from ETHospitalityWorld.com website: https://hospitality.economictimes.indiatimes.com/news/hotels/hyatt-to-lay-off-1300-employees-aspandemic-cripples-travel/75696297 (Accessed on: 23/ August / 2020)

Chaturvedi, A. (2020). Tourism and hospitality industry expresses shock and disappointment for no inclusion under Rs 20 lakh crore Atmanirbhar Bharat Abhiyan package. The Economic Times. Retrieved from https://economictimes.indiatimes.com/industry/services/travel/indian-tourism-industryin-a-state-of-disbelief-and-shock-faith/articleshow/75787447.cms?from=mdr (Accessed on: 01/ September / 2020)

Chowdhury, A. (2020a). Vistara implements leave without pay for $30 \%$ of staff; defers increments. The Economic Times. Retrieved from https://economictimes.indiatimes.com/industry/transportation/airlines/-aviation/vistara-implements-leave-without-pay-for-30-of-staff-defersincrements/articleshow/74849387.cms?from=mdr (Accessed on: 14/ April/2020)

Chowdhury, A. (2020b). IndiGo cuts salaries; SpiceJet stops overseas ops; AirAsia India halts fleet expansion, increments, hiring. The Economic Times. Retrieved from https://economictimes.indiatimes.com/industry/transportation/airlines-/-aviation/indigo-announces-paycut-for-all-employees-ceo-to-take-25-reduction/articleshow/74708383.cms?from=mdr (Accessed on: 16/ April/ 2020)

Das, G. (2020). 136 million jobs at risk in post-corona India. Livemint. Retrieved from https://www.livemint.com/news/india/136-million-jobs-at-risk-in-post-corona-india11585584169192.html (Accessed on: 12/ April/ 2020)

Joshi, A., Bhaskar, P., \& Gupta, P. K. (2020). Indian Economy Amid COVID-19 Lockdown: A Prespective. Journal of Pure and Applied Microbiology. Retrieved from https://microbiologyjournal.org/indianeconomy-amid-covid-19-lockdown-a-prespective/ (Accessed on: 03/ August / 2020) 
Kapoor, C. (2020). COVID-19: Informal sectors keep Indian economy on track. Aa.Com.Tr; Anadolu Agency, Çankaya ANKARA. Retrieved from https://www.aa.com.tr/en/asia-pacific/covid-19-informalsectors-keep-indian-economy-on-track-/1770246 (Accessed on: 8/ April/ 2020)

Mishra, A. R. (2020). Coronavirus outbreak may cost Indian economy $\$ 29.9$ bn: ADB. Retrieved from Livemint website: https://www.livemint.com/news/india/coronavirus-outbreak-in-india-could-cost-theeconomy-29-9-billion-adb-11583480504316.html (Accessed on: 25/ April/ 2020)

Mohile, S. S., \& Aute, S. (2020). Hotel owners consider salary cuts as cities go under coronavirus lockdown. Business Standard India. Retrieved from https://www.businessstandard.com/article/economy-policy/hotel-owners-consider-salary-cuts-as-cities-go-undercoronavirus-lockdown-120032401643_1.html (Accessed on: 27/ April/ 2020)

Nebehay, S., \& Mutikani, L. (2020). Tens of millions face losing jobs in escalating coronavirus crisis. Reuters. Retrieved from https://www.reuters.com/article/us-health-coronavirus-jobs/tens-of-millionsface-losing-jobs-in-escalating-coronavirus-crisis-idUSKBN21D374 (Accessed on: 13/ April/2020)

Press Trust of India (2020a). Coronavirus to impact India's economic growth "severely": D\&B. The Economic Times. Retrieved from https://economictimes.indiatimes.com/news/economy/indicators/coronavirus-to-impact-indiaseconomic-growth-severely-db/articleshow/74825429.cms (Accessed on: 15/ April/2020)

Press Trust of India. (2020b). COVID-19 pandemic impact: Majority of hotel operators expect up to 2 years for revenue recovery, says JLL survey. Retrieved from The Financial Express website: https://www.financialexpress.com/industry/covid-19-pandemic-impact-majority-of-hotel-operatorsexpect-up-to-2-years-for-revenue-recovery-says-|ll-survey/2009877/ (Accessed on: 03/ September/ 2020)

Press Trust of India. (2020c). Air India may cut salaries by 5\% amid coronavirus concerns. The Economic Times. Retrieved from https://economictimes.indiatimes.com/industry/transportation/airlines-/aviation/air-india-may-cut-salaries-by-5-amid-coronavirusconcerns/articleshow/74708732.cms?from=mdr (Accessed on: 19/ April/ 2020)

Press Trust of India. (2020d). GoAir offers rotational leave to staff without pay; mulls salary cut amid coronavirus pandemic. Www.Businesstoday.In. Retrieved from https://www.businesstoday.in/sectors/aviation/goair-offers-rotational-leave-to-staff-without-pay-mullssalary-cut-amid-coronavirus-pandemic/story/398503.html (Accessed on: 20/ April/2020)

Sharma, S. (2020). Big relief for Air India employees: No lay off plan on cards; no cut in Basic pay, DA, HRA. Retrieved from The Financial Express website: https://www.financialexpress.com/industry/bigrelief-for-air-india-employees-no-lay-off-plan-on-cards-no-cut-in-basic-pay-da-hra/2033262/(Accessed on: 03/ August / 2020)

Singh, V. A. (2020). Quarantine hotels: It's business unusual amid coronavirus outbreak. Business Standard India. Retrieved from https://www.business-standard.com/article/companies/quarantinehotels-it-s-business-unusual-amid-coronavirus-outbreak-120042400029_1.html

Sinha, S. (2020). IndiGo Layoffs: IndiGo to lay off 10\% employees | India Business News - Times of India. Retrieved from The Times of India website: https://timesofindia.indiatimes.com/business/indiabusiness/pandemic-impact-indigo-to-lay-off-10-employees/articleshow/77068489.cms (Accessed on: 03/ August / 2020)

World Health Organization. (2020a). Coronavirus disease (COVID-19) pandemic. Www.Euro.Who.Int. Retrieved from https://www.euro.who.int/en/health-topics/health-emergencies/coronavirus-covid19/novel-coronavirus-2019-ncov (Accessed on: 04/ September/ 2020) 
Joshi, A., Bhaskar, P.

COVID-19: IMPACT OF LOCKDOWN ON TOURISM \& HOSPITALITY INDUSTRY

World Health Organization. (2020b). WHO Coronavirus Disease (COVID-19) Dashboard. Retrieved from covid19.who.int website: https://covid19.who.int/ (Accessed on: 04/ September/ 2020) 